\title{
Effect of Real time nitrogen management on yield attributes of direct seeded rice by using SPAD meter and Greenseeker
}

\author{
SAISHREE ${ }^{*}$, Sabyasachi Biswal' ${ }^{1}$, Boyapati Ravi Teja Naidu² and Reddyyamini. \\ Bommisetty ${ }^{3}$. \\ Department of Agronomy, OUAT, Bhubaneswar-751 003. \\ Department of Plant Pathology, SBVR Agricultural college, Affliated to ANGRAU, Badvel- 516227. \\ Department of Genetics and Plant Pathology, SBVR Agricultural college, Affliated to ANGRAU, Badvel- \\ 516227.
}

\begin{abstract}
A field experiment was conducted during Kharif 2018, laid out in Randomized Block Design with three replications having seven treatments viz. $\mathrm{N}$ omission $\left(\mathrm{T}_{1}\right), \mathrm{N}$ applied as basal and AT $\left(\mathrm{T}_{2}\right), \mathrm{N}$ asbasal, AT and PI $\left(\mathrm{T}_{3}\right), \mathrm{N}$ as basal and top dressing at NDVI threshold of $0.75\left(\mathrm{~T}_{4}\right)$, at NDVI threshold of $0.8\left(\mathrm{~T}_{5}\right)$, at SPAD threshold of $35.0\left(\mathrm{~T}_{6}\right)$ and SPAD threshold of $37.5\left(\mathrm{~T}_{7}\right)$ with Rice variety Sahabhagidhan. The study revealed that application of $30 \mathrm{~kg} \mathrm{~N} / \mathrm{ha}$ as basal dose and top dressing of $20 \mathrm{~kg} \mathrm{~N} / \mathrm{ha}$ twice at 35 and 63 DAS guided by NDVI threshold value of $0.8\left(\mathrm{~T}_{5}\right)$ was found to be superior over other treatments with respect to productivity. $\mathrm{T}_{5}$ recorded highest grain yield of $4438 \mathrm{~kg} / \mathrm{ha}$ which was $17.0 \%$ higher than that top dressed at NDVI threshold of $0.75\left(\mathrm{~T}_{4}\right)$ and $7.1 \%$ higher than that top dressed at SPAD threshold value of $37.5\left(\mathrm{~T}_{7}\right)$. In case of SPAD meter, nitrogen top dressed at threshold value of $37.5\left(\mathrm{~T}_{7}\right)$ produced grain yield of $4143 \mathrm{~kg} / \mathrm{ha}$ which was $15.0 \%$ higher than $\mathrm{T}_{6} \cdot \mathrm{T}_{5}$ produced maximum dry matter of $8678 \mathrm{~kg} / \mathrm{ha}$ with highest grain yield (4438 $\mathrm{kg} / \mathrm{ha})$, straw yield(5092 kg/ha) and harvest index $46.0 \%$.
\end{abstract}

Keywords: NDVI, Nitrogen, Rice, SPAD meter, Yield.

\section{INTRODUCTION}

India is one of the leading rice producing countries of the world along with China, Thailand, Vietnam, USA and Pakistan. Global rice demand was 480 million tonnes in 2017-18 and is expected to rise to 496 million tons by 2020 and may further increase to 673 million tons by 2050 (FAO, 2013). India's share in global rice production is $21.5 \%$. It alone contributes to about 40 to $43 \%$ of the total food grain production and that is why the crop plays a vital role in national food and livelihood security mission. Rice export contributes about $25 \%$ of total agriculture export from the country. It provides about 700 calories/day/person to about 3000 
million people living mostly in the developing countries. Direct Seeded Rice (DSR) is gaining momentum owing to its advantages of less water requirement, over transplanted method since it does not require puddling and standing water. In addition to higher economic returns, the direct seeding of rice is easy to plant, less labour intensive and consumes less water.N loss due to denitrification, volatilization and leaching is likely to be higher in dry direct seeded rice (DDSR) than that in the transplanted rice. Ammonia volatilization is a major $\mathrm{N}$ loss when urea fertilizer is used in paddy soil, amounting to about 10-60\% of total applied $\mathrm{N}$ in rice fields (Tian et al., 2001 and Liang et al., 2007). Surface runoffaccounts for $1-13 \%$ of the total applied $\mathrm{N}$ (Blevins et al., 1996). As plant growth can reflect the total $\mathrm{N}$ supply from the soil, the plant $\mathrm{N}$ status is rather a better indicator of the $\mathrm{N}$ availability at any given time. Real time approach to $\mathrm{N}$ management is an easy, cost effective and reliable approach where the timing of $\mathrm{N}$ fertilizer applications is determined through periodic monitoring of crop N status. The tools such as GreenSeeker and SPAD meter is to guide fertilizer $\mathrm{N}$ applications to obtain a high-yield level along with improved $\mathrm{N}$-use efficiency comparable to that in blanket recommendations. Thus, the aim of this study is to assess to establish the threshold values of leaf greenness as measured by the GreenSeeker and SPAD to guide and formulate fertilizer $\mathrm{N}$ management strategies in dry direct seeded rice. In order to reduce the drudgery of the laboratory analysis, scientists have exploited crop sensor technology that gives information on the nitrogen need of a crop based on the leaf optical property. Since, leaf greenness or leaf $\mathrm{N}$ content is closely related to photosynthesis rate and biomass production, it is a sensitive indicator of changes in crop $\mathrm{N}$ demand during the growing season. Chlorophyll meter (SPAD) and GreenSeeker are such devices which can be effective in optimization and recommendation of nitrogen. The SPAD meter is a hand held, simple, quick and non-destructive tool for insitu measurement of relative content of chlorophyll in leaf that is directly proportional to leaf $\mathrm{N}$ content. Hence, the SPAD chlorophyll meter is used to diagnose the $\mathrm{N}$ status in crops and determine the right time of $\mathrm{N}$ application (Ladha et al., 2005). The SPAD meter measures how much of the lightof a certain wavelength is absorbed by the chlorophyll molecules leaf sample. Similarly, Normalized Difference Vegetation Index (NDVI) is a unit measured by an optical sensor which is based on the reflectance at red and Near Infrared (NIR) radiations. These values can be obtained by using a hand held device-GreenSeeker TM. NDVI measurements can range from -1 to1, with higher values indicating better plant health and higher chlorophyll content. TheNPK ratio of applied fertilizer is 6.7:2.7:1 whereas ideal ratio is 4:2:1 (Indian journal of fertilizers, 2017). At the same time, evaluation of these devices for their suitability and utility in the field of 
agriculture need to be addressed for better correlation of cropyields and also for their wider acceptability. It is suggested that different SPAD threshold and NDVI threshold values might to be used for different varietal groups andagro climatic conditions. (Balasubramarian et al., 2002 and Varinderpal Singh et al., 2010) Keeping this in view to enhance fertilizer nitrogen use efficiency and reduce fertilizer nitrogen related environmental pollution, the current study on "Real time nitrogen management in direct seeded rainfed rice using GreenSeeker and SPADmeter" has been contemplated to determine the critical thresholds of GreenSeeker (0.75 and 0.8) and SPAD (37 and 37.5) for rice crop.

\section{MATERIALS AND METHODS}

The experiment was conducted in the Instructional Farm of the College of Agriculture, Odisha University of Agriculture and Technology, Bhubaneswar during 2018. The field experiment was laid out in Randomized Block Design with three replications and seven treatments, gross plot size $7 \mathrm{~m} \times 5 \mathrm{~m}$, net plot size $6 \mathrm{~m} \times 4 \mathrm{~m}$. The Rice variety Sahabhagidhan was taken as the test cultivar in the experiment.

\section{Treatments}

Nutrition: (60-30-30 kg N-P $\left.\mathrm{O}_{5}-\mathrm{K}_{2} \mathrm{O}\right), \mathrm{P}_{2} \mathrm{O}_{5}$ basal, $\mathrm{K}_{2} \mathrm{O}$ as basal and at $\mathrm{PI}$
1. $\quad \mathbf{N}$ omission
2. $\quad \mathbf{N}$ as basal $\&$ at active tillering)
3. $\quad \mathbf{N}$ as basal, at active tillering \& panicle initiation)
4. $\quad \mathbf{N}$ as basal \& top dressing @ $20 \mathrm{~kg} / \mathrm{ha}$ at NDVI threshold of 0.75
5. $\quad \mathbf{N}$ as basal \& top dressing @ $20 \mathrm{~kg} / \mathrm{ha}$ at NDVI threshold of 0.80
6. $\quad \mathbf{N}$ as basal \& top dressing @ $20 \mathrm{~kg} / \mathrm{ha}$ at SPAD meter threshold of 35
7. $\quad \mathbf{N}$ as basal \& top dressing @ $20 \mathrm{~kg} / \mathrm{ha}$ at SPAD meter threshold of 37.5. 
Table 1. Nitrogen application schedules

\begin{tabular}{|c|c|c|c|c|c|c|c|c|c|c|c|}
\hline \multicolumn{12}{|l|}{ Table 1. Nitrogen application schedules } \\
\hline \multirow[t]{2}{*}{ Treatment } & \multicolumn{11}{|c|}{ Nitrogen application (DAS) } \\
\hline & 0 & 28 & 35 & 42 & 49 & 56 & 63 & 70 & 77 & 84 & $\begin{array}{l}\text { Total } \\
(\mathrm{kg} / \mathrm{ha})\end{array}$ \\
\hline$T_{1}: \mathrm{N}$ omission (control) & 0 & 0 & 0 & 0 & 0 & 0 & 0 & 0 & 0 & 0 & 0 \\
\hline $\mathrm{T}_{2}: \mathrm{N}$ (Basal and AT) & 30 & 0 & 30 & 0 & 0 & 0 & 0 & 0 & 0 & 0 & 60 \\
\hline $\mathrm{T}_{3}: \mathrm{N}$ (Basal, AT and PI) & 30 & 0 & 15 & 0 & 0 & 15 & 0 & 0 & 0 & 0 & 60 \\
\hline $\mathrm{T}_{4}: \mathrm{N}$ (Basal and NDVI threshold of 0.75) & 30 & 0 & 0 & 20 & 0 & 0 & 0 & 0 & 20 & 0 & 70 \\
\hline $\mathrm{T}_{5}: \mathrm{N}$ (Basal and NDVI threshold of 0.8 ) & 30 & 0 & 20 & 0 & 0 & 0 & 20 & 0 & 0 & 0 & 70 \\
\hline $\mathrm{T}_{6}: \mathrm{N}$ (Basal and SPAD threshold of 35) & 30 & 0 & 0 & 20 & 0 & 0 & 0 & 0 & 20 & 0 & 70 \\
\hline $\mathrm{T}_{7}: \mathrm{N}$ (Basal and SPAD threshold of 37.5) & 30 & 0 & 20 & 0 & 0 & 0 & 0 & 20 & 0 & 0 & 70 \\
\hline
\end{tabular}




\section{Biometric observation}

\section{Sampling technique}

Two rows of one meter length from 3 different location of each plot were randomlyselected and observations on plants height and number of tillers were recorded. Destructive samples were drawn from the third row form the net plot on each side of the plots. Observation on leaf area and dry matter accumulation were recorded from continious clumps from $0.5 \mathrm{~m}$ length from four spots. Border rows were not sampled to avoid bordereffects.

\section{PRE-HARVEST STUDY}

Plant height,tiller number,leaf area Index,Crop Growth Rate are carried out according to SES IRRI Rice

\section{Measurement of spectral properties of leaves}

Spectral properties of rice leaves were measured using SPAD 502 chlorophyll meter and GreenSeeker optical sensor. Spectral properties were measured at 7 days intervalstarting from 28 DAS to initiation of flowering. GreenSeeker and SPAD meter readings were recorded on 4, 11, 18 and 25 of Aug, 02, 09, 16, 23 of Sept.

\section{SPAD 502 chlorophyll meter measurement}

Chlorophyll meter are reliable alternatives to traditional tissue analysis as plant $\mathrm{N}$ nutritional diagnostic tools. These instantly provide an estimate of leaf $\mathrm{N}$ status aschlorophyll content by clamping the unplucked leafy tissue in the meter. It has two LEDs (light emitting diodes) which emitted light with a peak wavelength of $650 \mathrm{~nm}$ and an infrared radiation peak wavelength of $940 \mathrm{~nm}$. The red and infrared radiation are made to pass through the ${ }^{2}$ leaf. A portion of light is absorbed and the remainder is transmitted through the leaf and silicon photodiode detector converts it into an electrical signal. The amount of light reaching the photodiode detector is inversely proportional to the amount of chlorophyll in the path of the light. Leaf chlorophyll content is displayed in arbitrary units (0-99.9). The SPAD meter reading are unit less and need to be calibrated with chlorophyll or $\mathrm{N}$ content and leaf greenness. The SPAD meter is the one tool that enables to determine the relative amount of chlorophyll content by measuring leaf greenness (Peterson et al., 1993) and the linear relationship of SPAD values and N status in 
crops varies depending on the growth stages and cultivars. Since chlorophyll content is usually strongly related to $\mathrm{N}$ concentration, SPAD meters can be used as indicator of need for $\mathrm{N}$ application (Schepers et al.,1992, Blackmer and Schepers, 1995). The top most fully expanded leaf is usually considered as the index leaf to reflect $\mathrm{N}$ status of the plant. The SPAD meter uses a silicon photodiode to derive the ratio of transmittance through the leaf tissue at $650 \mathrm{~nm}$ compared with transmittance at $940 \mathrm{~nm}$ and a value is given based on thatratio.

SPAD meter reading were taken with a Minolta 502 Chlorophyll meter starting from 28 DAS. Before taking readings, the meter was calibrated by switching on the meter with no leaf sample slot, followed by complete closing the measuring head until a beep sound was heard. The meter was thus calibrated and ready for measurements.

SPAD meter reading were recorded from the uppermost fully expanded leaf of 5 randomly selected plants at 7 days interval till the flowering. The receiving window of the chlorophyll meter was cleaned with a soft cloth before taking measurements. The extremely thick, disease affected and insect bitten leaves were avoided for measurement. The data was recorded when leaves were dry. The selected leaf was inserted into sample slot of measuring head of chlorophyll meter to make sure that the sample was completely covered by the receiving window. The measuring head was completely closed until a beep sound was heard which indicated that measurement was over and the value appeared on the display. The chlorophyll reading was automatically saved in the meter. The head was opened and the reading for next leaf was taken on the same way. The average of all the SPAD readings for a plot was the noted. After noting SPAD value of the plot, the meter was cleared for the next set of reading by pressing the "all data clear" button. The old readings were deleted by pressing the button "one data clear" before taking average.

\section{GreenSeeker optical sensor}

3

GreenSeeker $^{\mathrm{TM}}$ handheld optical sensor (NTech industries, Inc. Ukiah. CA.) developed by Oklahoma State University, senses a 0.6 x $0.01 \mathrm{~m}$ area when held at a distance approximately $67 \mathrm{~cm}$ from the illuminated surface. The sensed dimensions remainapproximately constant over the height range of sensor. The sensor unit has self-containedillumination in both red $(671+6$ $\mathrm{nm})$ and near infrared (NIR) $(780+6 \mathrm{~nm})$ bands. The device measures the fraction of emitted light in the sensed area that is reflected back to thesensor (reflectance). Chlorophyll contained in the palisade layer of the leaf controls much of the visible light $(400-720 \mathrm{~nm}$ ) reflectance. Chlorophyll absorbs between 70 to $90 \%$ of all incident light in the blue and red wavelength 
bands while reflecting light in the green band (Campbell 2002). The amount of light reflected in the visible region is defined by the chlorophyll content in the cell and the amount of light reflected in the near infrared (NIR) region is defined by living vegetation or biomass. The amount of blue and red light absorbed by the leaf is proportional to the chlorophyll density of the leaf. Reflectance of the NIR portion of the electromagnetic spectrum (720-1300 nm) is predominantly influenced by the mesophyll cells. The upper layers of the leaf are nearly transparent to NIR energy. Mesophyll tissue scatters and reflects as much as 60 per cent of all incident NIR radiation. The degree to which near infrared energy is reflected depends on the structure of the mesophyll cells and cavities between these cells (Campbell 2002). Several researchers have assessed $\mathrm{N}$ status and other physiological parameters of field crops using optical sensors (Zhao et al., 2017). The GreenSeeker ${ }^{\mathrm{TM}}$ hand heldoptical sensor unit Model 505 was used to measure NDVI from the crop canopy. Before taking the readings, battery was charged properly. Then shoulder strap was put around the body and sensor angle were such adjusted that it was parallel to sensing area at a height of about $70 \mathrm{~cm}$ above the crop canopy. The trigger of GreenSeeker optical sensor was pressed continuously. while moving in the two middle crop rows and trigger was released after completing one plot. After that note down the value which was displayed on the machine. Normalized Difference Vegetation Index (NDVI) measurement made by GreenSeeker computed by the following equation.

$\mathrm{NDVI}=(\mathrm{NIR}-\mathrm{RED}) /(\mathrm{NIR}+\mathrm{RED})$

Where NIR or RED represents reflectance in the near infrared and red bands.

\section{Post harvest study}

Panicle number, Panicle length, Number of grains,Spikelet sterility,Test weight,Grain and straw yield,Harvest index allobserverations are carried out according to SES (2013 IRRI).

\section{RESULTS}




\section{Number of effective tillers}

The data pertaining to tiller production is presented in the Table 2. The production of effective tillers was influenced by different nitrogen application schedules. It ranged from $183 / \mathrm{m}^{2}$ to $315 / \mathrm{m}^{2}$ in different treatments.

The highest number of effective tillers was recorded in $\mathrm{T}_{5}\left(315 / \mathrm{m}^{2}\right)$ where nitrogentop dressing was guided by NDVI threshold of 0.8 which was at par with $\mathrm{T}_{7}\left(312 / \mathrm{m}^{2}\right)$ whereit was guided by SPAD threshold of 37.5 , but significantly higher than $\mathrm{T}_{4}\left(303 / \mathrm{m}^{2}\right)$ and $\mathrm{T}_{6}\left(229 / \mathrm{m}^{2}\right)$ where it was guided by NDVI threshold of 0.75 and SPAD threshold of 35.0, respectively. It was also higher than the treatments with blanket recommendation. However, no significant difference was obtained between $\mathrm{T}_{3}\left(280 / \mathrm{m}^{2}\right)$ where nitrogen top dressed twice at AT and PI and $\mathrm{T}_{2}\left(271 / \mathrm{m}^{2}\right)$ where entire nitrogen was top dressed only at AT, respectively. The number of effective tiller was the lowest in $\mathrm{T}_{1}\left(183 / \mathrm{m}^{2}\right)$ where no nitrogen was applied.

\section{Grain production}

The data on production of grains per panicle as influenced by nitrogen applicationschedules are presented in Table 2.Total number of grains ranged from 72.1 to 105.3 in different treatments.Highest number of grains per panicle (105.3) was observed in $\mathrm{T}_{5}$ where nitrogen top dressing was guided by NDVI threshold of 0.8. It was at par with $\mathrm{T}_{7}$ (103.1), $\mathrm{T}_{4}(98.5)$ and $\mathrm{T}_{6}$ (103.7) where it was guided by SPAD threshold of 37.5, NDVI threshold of 0.75 and SPAD threshold of 35.0, respectively, but higher than that under blanket top dressings. However, no significant difference was obtained between $\mathrm{T}_{3}$ (86.0) where nitrogen was topdressed at AT and $\mathrm{PI}$ and $\mathrm{T}_{2}$ (82.6) entire nitrogen was top dressed only once at AT. But the grain production was markedly reduced in $\mathrm{T}_{1}$ (72.1) which was grown without nitrogenapplication.

\section{Filled grains per panicle}

5

The data on production of filled grains per panicle as influenced by nitrogen application schedules are presented in Table 2. Filled grains per panicle ranged from 60.6to 99.4 in different treatments.

Highest number of filled grains was found in $\mathrm{T}_{5}$ (99.4) where nitrogen top dressing was guided by NDVI threshold of 0.8 which was at par with that in $\mathrm{T}_{7}(95.1)$ where nitrogentop dressing was guided by SPAD threshold of 37.5. But it was higher than $\mathrm{T}_{4}(95.9)$ and $\mathrm{T}_{6}(92.9)$ where it was guided by NDVI threshold of 0.75 and SPAD threshold of 35.0, respectively. It was also higher 
than that under blanket recommendation. No significant difference between $T_{3}$ (78.9) when nitrogen was top dressed either twice at AT and PI and $\mathrm{T}_{2}$ (74.9) where it was top dressed only once at AT. However, $\mathrm{T}_{1}$ (60.6) recorded the lowestfilled grain per panicle, where no nitrogen was supplied.

\section{Sterility}

Sterility of grains differed with different nitrogen application schedules. The data related to sterility per cent are presented in Table 2 . It ranged from $6.7 \%$ to $15.9 \%$ in different nitrogen application schedules.

The lowest sterility was recorded in $\mathrm{T}_{5}(6.7 \%)$ where nitrogen top dressing was guided by NDVI threshold of 0.8 which was significantly lower than rest of the treatments. Sterility obtained where $\mathrm{T}_{7}(7.4 \%)$ where nitrogen top dressing was guided by SPAD threshold of 37.5, $\mathrm{T}_{4}(7.5 \%)$ where it was guided by NDVI threshold of 0.75 and $\mathrm{T}_{6}(7.8 \%)$ where it was guided by SPAD threshold of 35.0, were at par. The sterility in $\mathrm{T}_{3}(13 \%)$ where nitrogen was top dressed in two splits at AT and PI was significantly lower than $\mathrm{T}_{2}(14.8 \%)$ where it was top dressed only at AT. However maximum sterility was recorded in $\mathrm{T}_{1}(15.9 \%)$ where no nitrogen was applied.

\section{Test weight}

Data recorded on 1000-grain weight are presented in Table 2.. It differed significantly among different nitrogen application schedules. Test weight of grains rangedfrom $23.8 \mathrm{~g}$ to $18.1 \mathrm{~g}$ in different treatments.

Highest test weight was recorded in $\mathrm{T}_{5}(23.8 \mathrm{~g})$ where nitrogen top dressing was guided by NDVI threshold of 0.8 which was at par with $\mathrm{T}_{7}(23.5 \mathrm{~g})$ where nitrogen top dressing was guided by SPAD threshold 37.5, but was higher than $\mathrm{T}_{4}(23.1 \mathrm{~g})$ and $\mathrm{T}_{6}(23.1 \mathrm{~g})$ where it was guided by NDVI threshold of 0.75 and SPAD threshold of 35.0, respectively. These were also significantly higher than $\mathrm{T}_{3}(22.6 \mathrm{~g})$ where nitrogen was topdressed at AT and PI and $\mathrm{T}_{2}(21.6$ g) where entire nitrogen top dressed only at AT, who were at par with each other. However, the test weight was the lowest in $\mathrm{T}_{1}(18.1 \mathrm{~g})$ with nitrogen omission.

\section{Grain yield}

The data pertaining to grain yield as influenced by different nitrogen application schedules are presented in Table 2.. Different nitrogen application schedules caused significant variation in grain yield in all the treatments. 
Grain yield ranged from $1509 \mathrm{~kg} / \mathrm{ha}$ to $4438 \mathrm{~kg} / \mathrm{ha}$ in different treatments with an average yield of $3358 \mathrm{~kg} / \mathrm{ha}$. Maximum grain yield of $4438 \mathrm{~kg} / \mathrm{ha}$ was obtained in $\mathrm{T}_{5}$ where nitrogen top dressing was guided by NDVI threshold of 0.8. This was significantly higher than $\mathrm{T}_{4}(4712$ $\mathrm{kg} / \mathrm{ha}$ ) with NDVI threshold of 0.75 and also higher than $\mathrm{T}_{7}$ and $\mathrm{T}_{6}$ where nitrogen top dressing was guided by SPAD threshold of 37.5 and 35.0, respectively. Yield obtained under SPAD threshold of 37.5 (4143 kg/ha) was also significantly higher than SPAD threshold of 35.0 (3385 $\mathrm{kg} / \mathrm{ha})$.

The grain yield obtained by optical sensor guided nitrogen application was higher than that fixed applications. A grain yield of $4155 \mathrm{~kg} / \mathrm{ha}$ was recorded with blanket top dressing at AT and PI $\left(\mathrm{T}_{3}\right)$ which was significantly higher than $\mathrm{T}_{2}(3428 \mathrm{~kg} / \mathrm{ha})$ with only one top dressing at AT. However, the yield obtained with nitrogen omission $\left(\mathrm{T}_{1}\right)$ was the lowest $(1887 \mathrm{~kg} / \mathrm{ha})$.

\section{Straw yield}

The data pertaining to straw yield as influenced by different nitrogen application schedules are presented in Table 2. Different nitrogen application schedules caused significant variation in straw yield in all the treatments.

Straw yield ranged from $2000 \mathrm{~kg} / \mathrm{ha}$ to $5092 \mathrm{~kg} / \mathrm{ha}$ in different treatments with an average yield of $3950 \mathrm{~kg} / \mathrm{ha}$. Maximum straw yield was obtained in $\mathrm{T}_{5}(5092 \mathrm{~kg} / \mathrm{ha})$ where nitrogen top dressing was guided by NDVI threshold of 0.8 which was at par with $\mathrm{T}_{7}(5900 \mathrm{~kg} / \mathrm{ha})$ where it was guided by SPAD threshold of 37.5 , but was significantly higher than $\mathrm{T}_{4}(5433 \mathrm{~kg} / \mathrm{ha})$ with NDVI threshold of 0.75 and $\mathrm{T}_{6}(5100 \mathrm{~kg} / \mathrm{ha})$ with SPAD threshold of

35.0. Straw yield obtained under SPAD threshold of 37.5 was also significantly higher than SPAD threshold of 35.0.

The straw yield obtained by optical sensor guided nitrogen application was higher than that under fixed applications. A straw yield of $4800 \mathrm{~kg} / \mathrm{ha}$ was recorded with blankettop dressing of nitrogen twice at AT and PI $\left(\mathrm{T}_{3}\right)$ which was significantly higher than $\mathrm{T}_{2}(4266 \mathrm{~kg} / \mathrm{ha})$ with only one top dressing at AT. However, the yield obtained with nitrogenomission $\left(\mathrm{T}_{1}\right)$ was the lowest $(2500 \mathrm{~kg} / \mathrm{ha})$.

\section{Harvest index}

Data on harvest index $(\mathrm{HI})$ of rice grown under different nitrogen application schedules are 
presented in Table 2.

The harvest index ranged from $43.0 \%$ to $46.7 \%$ in different treatments. Maximumharvest index was recorded in $\mathrm{T}_{5}(46.7 \%)$ where nitrogen top dressing was guided by NDVIthreshold of 0.8 followed by $\mathrm{T}_{6}(46.5 \%), \mathrm{T}_{4}(46.5 \%)$ and $\mathrm{T}_{7}(45.9 \%)$ where nitrogen top dressing was guided SPAD threshold 35.0, NDVI threshold 0.75 and SPAD threshold 37.5, respectively. Under blanket top dressing of nitrogen AT and PI (46.4\%) was higher than $\mathrm{T}_{2}(44 \%)$ where entire nitrogen was top dressed only at AT. But the harvest index was restricted to only $43 \%$ in $\mathrm{T}_{1}$ with nitrogen omission. 
Table 2. Effect of nitrogen application schedules on yield attributes and yield

\begin{tabular}{|c|c|c|c|c|c|c|c|c|c|}
\hline Treatment & $\begin{array}{l}\text { Effective } \\
\text { tillers/m² }\end{array}$ & $\begin{array}{l}\text { Panicle } \\
\text { length } \\
(\mathrm{cm})\end{array}$ & $\begin{array}{l}\text { Total } \\
\text { grains/ } \\
\text { panicle }\end{array}$ & \begin{tabular}{|l} 
Filled \\
grains/ \\
panicle
\end{tabular} & $\begin{array}{l}\text { Sterility } \\
(\%)\end{array}$ & $\begin{array}{l}\text { Test } \\
\text { wt (g) }\end{array}$ & $\begin{array}{l}\text { Grain } \\
\text { yield } \\
\text { (kg/ha) }\end{array}$ & \begin{tabular}{|l|} 
Straw \\
yield \\
(kg/ha)
\end{tabular} & $\begin{array}{l}\text { HI } \\
(\%)\end{array}$ \\
\hline$T_{1}: \mathrm{N}$ omission (control) & 183 & 16.5 & 72.1 & 60.6 & 15.9 & 18.1 & 1509 & 2000 & 43.0 \\
\hline$T_{2}: \mathrm{N}$ (Basal and AT) & 271 & 19.8 & 82.6 & 70.3 & 14.8 & 21.6 & 2742 & 3412 & 44.0 \\
\hline$T_{3}: \mathrm{N}$ (Basal, AT and PI) & 280 & 21.4 & 86.0 & 74.9 & 13.0 & 22.6 & 3324 & 3840 & 46.4 \\
\hline$T_{4}: \mathrm{N}$ (Basal and NDVI threshold of 0.75) & 303 & 23.0 & 98.5 & 91.1 & 8.0 & 23.1 & 3770 & 4346 & 46.5 \\
\hline$T_{5}: \mathrm{N}$ (Basal and NDVI threshold of 0.8) & 315 & 25.4 & 105.3 & 99.4 & 6.7 & 23.8 & 4438 & 5092 & 46.7 \\
\hline$T_{6}: \mathrm{N}$ (Basal and SPAD threshold of 35.0) & 299 & 22.5 & 95.7 & 88.2 & 7.8 & 23.1 & 3585 & 4080 & 46.5 \\
\hline$T_{7}: \mathrm{N}$ (Basal and SPAD threshold of 37.5) & 312 & 24.6 & 103.1 & 95.1 & 7.7 & 23.5 & 4143 & 4880 & 45.9 \\
\hline SE m \pm & 4.20 & 0.66 & 4.30 & 2.10 & 0.55 & 0.18 & 20.32 & 159.30 & 0.01 \\
\hline $\mathrm{CD}(0.05)$ & 12.90 & 2.04 & 13.30 & 6.50 & 1.70 & 0.56 & 62.58 & 490.80 & 0.03 \\
\hline
\end{tabular}




\section{DISCUSSION}

\section{Crop and weather}

Temperature, solar radiation (light intensity and duration) and relative humidity significantly influence and control the growth. It accounts for $76 \%$ of variation in crop productivity (Ram Krishna et al., 2000). Rice plant is highly adoptable to its environmentand can grow under wide range of seasonal variations. However, higher yield can only be achieved with optimum interplay of various weather elements, a condition of atmosphere at a given time and space.

Rice is considered as a tropical region crop, comprising of tropic of Cancer $\left(23^{0} 27^{\prime} \mathrm{NL}\right)$ and tropic of Capricorn $\left(23^{0} 27^{\prime} \mathrm{SL}\right)$. The experimental site $\left(20^{0} 15^{\prime} \mathrm{NL}\right)$ being close to the tropical region provides a typical environment for the growth of the plants. Extreme temperature is destructive for plant growth. Depending on growth stages, injury to rice mayoccur when the daily mean temperature drops below $20^{\circ} \mathrm{C}$ or rise above $35^{\circ} \mathrm{C}$ (Yoshida, 1981). During the period of rice growth, the average daily temperature ranged between $21^{\circ} \mathrm{C}$ to $33^{\circ} \mathrm{C}$ in kharif. Both the maximum $\left(\mathrm{T}_{\max }\right)$ and minimum $\left(\mathrm{T}_{\min }\right)$ temperatures governthe growth as well as the yield of rice. Rice crop requires average daily temperature of $26.5^{\circ} \mathrm{C}$ to $29.5^{\circ} \mathrm{C}$ for blooming but during that period the average temperature was $25.2{ }^{\circ} \mathrm{C}$ to $32.6{ }^{\circ} \mathrm{C}$. This might be the reason for increased sterility and lower yield. Bright sunshineis the source of energy to produce and accumulate food in different sinks at different periods of growth. Moomaw and Vergara (1964) reported that the accumulated sunshine hours should be around $240 \mathrm{hrs}$ from flower initiation to physiological maturity for higherdry matter accumulation in grains. The mean bright sunshine hour was of 6.2 hrs, which justifies the yield.

\section{Yield and yield attributes}

Yield is a function of the yield attributes of a plant. The major yield attributing characters are number of ear bearing tillers, number of grains per panicle, filled grains per panicle and test weight. Usually, there exists a positive relation of these parameters with yield. But this is not always true as negative correlation may also exist beyond certain level. In the present investigation, yield attributing characters viz. number of panicles, number of grains per panicle, filled grains per panicle and test weight were markedly influenced by different nitrogen application schedules. 
Grain yield of cereals is highly dependent upon the number of effective tillers produced by each plant as yield is function of number of ear bearing tillers per unit area (Power and Alessi, 1978 and Nerson, 1980). Lee et al. (2010) stated that effective paniclenumber is considered to be the main factor for determining yield because the effect of increase in panicle number per unit area is similar to that of increasing rice yield. When top dressing of nitrogen was guided by NDVI threshold value $\mathrm{T}_{5}$ (threshold of 0.8 ) more number of effective tillers $\left(315 / \mathrm{m}^{2}\right)$ were produced which were $3.9 \%$ higher than $\mathrm{T}_{4}$ (threshold of 0.75 ). When nitrogen top dressing was guided by SPAD threshold value $\mathrm{T}_{7}$ (threshold of 37.5 ) more number of effective tillers $\left(312 / \mathrm{m}^{2}\right.$ ) were produced which were $4.1 \%$ higher than $\mathrm{T}_{6}$ (threshold of 35.0). But when fixed time schedules were followed, topdressing twice at AT and PI ( $\left.\mathrm{T}_{3}\right)$ produced 280 effective tillers $/ \mathrm{m}^{2}$ which were $3.3 \%$ higherthan that top dressed once at AT $\left(\mathrm{T}_{2}\right)$. However, the maximum number of effective tillers were produced under $T_{5}$ which was $12 \%$ higher than $T_{3}$. However, the lowest effective tillers were obtained in $T_{1}\left(193 / \mathrm{m}^{2}\right)$ with nitrogen omission. Since SPAD readings are affected by leaf water content and irradiance, SPAD measurements might change throughout the day in parallel with the daily changes in photon flux density and leaf water status. The progressive improvement in the in formation of tillers might be due to increase in nitrogen use efficiency which enhanced tillering. Adequacy of nitrogen probablyfavoured the cellular activities during panicle formation and development which led to increased number of productive tillers. The reason for more number of effective tillers might be due to higher LAI resulting increased photosynthetic ability and dry matter accumulation and reduced tiller mortality thereby increasing the proportion of effective tillers to total tillers.

The maximum lengths of panicles were recorded under $\mathrm{T}_{5}$ which were $3.2 \%$ higherthan that of $\mathrm{T}_{7}$ and $11 \%$ higher than $\mathrm{T}_{3}$. The lowest sterility was recorded in $\mathrm{T}_{5}(6.7 \%)$ where nitrogen top dressing was guided by NDVI threshold of 0.8 . It was $8.0 \%$ lower than $\mathrm{T}_{4}$ (threshold of 0.75 ). In $\mathrm{T}_{7}$ (threshold of 37.5) 7.7\% sterility was noticed which was $7.8 \%$ lower than $\mathrm{T}_{6}$ (threshold of 35.0). But when fixed time schedules were followed, topdressing twice at AT and PI $\left(\mathrm{T}_{3}\right)$ recorded $13.0 \%$ sterility which was $12.1 \%$ lower thanthat top dressed once at AT $\left(\mathrm{T}_{2}\right)$.

The total number of grains per panicle (filled grains) is an important parameter which contributes towards grain yield. Hasegawa et al. (1994) indicated that increased number of spikelets and vigorous growth of rice due to high rates of $\mathrm{N}$ fertilizer application induced 
competition for carbohydrate available for grain filling and spikelet formation. This was in agreement with the findings of Channabasavanna and Setty (1994). Blanket recommendation of nitrogen top dressing at AT and PI $\left(\mathrm{T}_{3}\right)$ produced 74.9 filled grain perpanicle, which was $6.5 \%$ higher than that under $\mathrm{T}_{2}$ where it was top dressed only once AT. The overall number of filled grains obtained under $\mathrm{T}_{5}$ was $4.5 \%$ higher than $\mathrm{T}_{7}$ and $26 \%$ higher than $\mathrm{T}_{3}$. This might be due to adequate nitrogen supply which resulted in higher photosynthate accumulation and translocation of these photosynthates to the reproductivepart there by increasing the number of filled grains per panicle. Sun et al. (2012) reported that increased N application at later growth stages could result in a continuous uptrend in the number of spiklets per panicle and attributed this to better nitrogen status of plant during panicle growth period. But due to insufficient nitrogen supply, highest sterility per cent was recorded in $\mathrm{T}_{1}(19.1 \%)$ where no nitrogen was applied. Moreover, the increase in panicle length also helped in accommodating higher number of grains per panicle. The results are in conformity with the findings of Mahajan et al. (2011). Fageria et al.(2010) noticed that spikelet sterility accounted for $7 \%$ variation in yield and $3 \%$ variation in test weight.

Grain weight, an important yield determining attribute, is a genetic character least influenced by environment. However favourable environment at grain filling stage ensured higher grain weight. Higher test weight was recorded in $\mathrm{T}_{5}(23.8 \mathrm{~g})$ followed by $\mathrm{T}_{7}(23.5 \mathrm{~g}), \mathrm{T}_{4}(23.1 \mathrm{~g})$ and $\mathrm{T}_{6}(23.1 \mathrm{~g})$ which was higher than blanket recommendation $\mathrm{T}_{3}(22.6 \mathrm{~g})$ and $\mathrm{T}_{2}(21.6 \mathrm{~g})$. The increase in test weight in optical sensor guided treatments might be due to proper time of nitrogen application which increased photosynthetically active period and translocated the photosynthates more efficiently to thegrains for a longer period extended with duration resulting in well filled grains.

The grain yield expression is basically a function of absolute infrastructure and seeddevelopment activity of plant (Pandey et al., 1991). It is also a cumulative effect of severalgrowth regulating factors consisting mainly of genetic, environmental and management aspects dovetailed one into other to meet the optimum need of the crop at different stages of growth. According to Dobbemann and Fairhurst (2000) top dressing with split application of nitrogen is needed when the crop has a great need for it and when the rate ofnitrogen uptake is large. When nitrogen top dressing was guided by NDVI threshold of 0.8 , maximum yield was obtained in $\mathrm{T}_{5}(4438 \mathrm{~kg} / \mathrm{ha})$ 
which was $17 \%$ higher than $\mathrm{T}_{4}$ (NDVI threshold of 0.75 ). When nitrogen top dressing was guided by SPAD threshold of 37.5, it recorded a higher yield of $5179 \mathrm{~kg} / \mathrm{ha}\left(\mathrm{T}_{7}\right)$ which was $15 \%$ higher than $\mathrm{T}_{6}$ (SPAD threshold of 35). But when fixed time schedules were followed top dressing twice at AT and PI ( $\left.\mathrm{T}_{3}\right)$ recorded yield of $3324 \mathrm{~kg} / \mathrm{ha}$ which was $20 \%$ higher than that top dressed only once at AT $\left(\mathrm{T}_{2}\right)$. However, the highest yield recorded under $\mathrm{T}_{5}$ was $7.1 \%$ higher than that of $\mathrm{T}_{7}$ and $30 \%$ higher than $\mathrm{T}_{3}$. The lowest yield was obtained under nitrogen omission was (1509 kg/ha). Hirzel et al. (2011) confirmed the low grain yield record from the basal applicationof the entire recommended dose at planting. This could be due to low available nitrogen from loss by denitrification, leaching and volatilization.

When NDVI value 0.75 and 0.8 were used as critical values for applying $20 \mathrm{kgN} / \mathrm{ha}$ to rice irrespective of basal application, accordingly grain yield of these treatments was significantly higher than blanket application. Yield obtained under NDVI threshold of 0.8 was also higher than NDVI threshold of 0.75 . where he witnessed that the yield at NDVI threshold 0.8 was significantly higher than SPAD 40 and LCC 4 and 5. This is because NDVI considers only crop reflectance, but SPAD considers both chlorophyll content and soil characterstics. That is why in SPAD thresholds fertilizer application was 7-10 days later than NDVI thresholds. When SPAD value of 35.0 and 37.5 were used as critical values for applying 20 $\mathrm{kgN} / \mathrm{ha}$ to rice irrespective of basal application, accordingly grain yield of these treatments were significantly higher than blanket application. Yield obtained under SPAD threshold of 37.5 was also higher than SPAD threshold of 35.0. These results are incontrasts to findings of Peng et al. (1996) in Philippines that nitrogen management based on a critical SPAD value of 35.0 could produce yields in IR72 similar to those obtained by applying $120 \mathrm{~kg} / \mathrm{ha}$. This may due to difference in rice cultivars as well as growing conditions between the Philippines and Eastern India. It has been suggested that different SPAD threshold values may have to be used for different varietal groups and agro climatic conditions. (Balasubramarian et al., 2002 and Varinderpal Singh et al.,2010). But Bijay Singh et al. (2002) found SPAD threshold of 37.5 appropriate for rice cultivars PR 106 andPR111.

When nitrogen top dressing was guided by NDVI threshold of 0.8 , maximum straw yield was obtained in $\mathrm{T}_{5}(5092 \mathrm{~kg} / \mathrm{ha})$ which was $17.1 \%$ higher than $\mathrm{T}_{4}$ (NDVI threshold of 0.75$)$. When nitrogen top dressing was guided by SPAD threshold of 37.5 recorded higher yield of 4880 
$\mathrm{kg} / \mathrm{ha}\left(\mathrm{T}_{7}\right)$ which was $19.6 \%$ higher than $\mathrm{T}_{6}$ (SPAD threshold of 35). But when fixed time schedules were followed topdressing twice at AT and PI $\left(\mathrm{T}_{3}\right)$ recordedyield of $3840 \mathrm{~kg} / \mathrm{ha}$ which was $12.5 \%$ higher than that top dressed once at AT $\left(\mathrm{T}_{2}\right)$. However, the highest yield recorded under $\mathrm{T}_{5}$ was $4.3 \%$ higher than that of $\mathrm{T}_{7}$ and $32 \%$ higher than $\mathrm{T}_{3}$. The lowest straw yield obtainedwith nitrogen omission was $2000 \mathrm{~kg} / \mathrm{ha}$. This might be due to better availability of nutrients with increased nitrogen application, which resulted in higher dry matter accumulation in subsequent growth stages and ultimately resulting in the highest straw yield. The results are in accordance with the findings of Bijay Singh et al. (2002).

Although HI value was having significant correlation with grain yield, efficiency of grain production in crop plants is frequently expressed as HI. Maximum HI was recordedin $\mathrm{T}_{5}(46.7 \%)$ where top dressing of nitrogen was guided by NDVI threshold of 0.8 which was higher than $\mathrm{T}_{4}$ $(46.5 \%)$ where it was guided by NDVI threshold of 0.75 . When nitrogentop dressing was guided by SPAD threshold of 37.5 obtained $\mathrm{HI}$ of $45.9 \%\left(\mathrm{~T}_{7}\right)$ which was very close to $\mathrm{T}_{6}$ (SPAD threshold of 35.0). But when fixed time schedules were followed,top dressing twice at AT and PI $\left(\mathrm{T}_{3}\right)$ obtained HI of $46.5 \%$ which was $5.4 \%$ higher than that top dressed once at AT $\left(\mathrm{T}_{2}\right)$. However, the highest $\mathrm{HI}$ obtained under $\mathrm{T}_{5}$ was $17 \%$ higher than that of $\mathrm{T}_{7}$ and $6 \%$ higher than $\mathrm{T}_{3}$. Maximum harvest index was found in $\mathrm{T}_{5}$, because of higher grain yield comparative to corresponding straw yield that might have resulted due to proper availability of nutrients, which ultimately lead to higher LAI, high dry matter accumulation and translocation, production of higher panicle bearing tillers perunit area and more number of filled grains per panicle Sidhu. Better chlorophyll development that might have improved the vegetative and reproductive growth of the crop influenced directly or indirectly for higher production under higher fertilizer uptake. More over sustaining higher leaf area due to balanced plant food available in post flowering phase might have encouraged dry matter partitioning leading to better grain filling and higher test weight realizing higher grain yield. Artacho (2009) believed that HI, which is the ratio of grain yield to total biomass, was not affected by $\mathrm{N}$ fertilization. But present experiment was in contrast to that. Fageria et al. (2010) explained that the HI represents partitioning of photosynthate between grain and vegetative plant parts. 


\section{CONCLUSION}

Real time approach to nitrogen management is cost effective and reliable where the timing of nitrogen application is determined through periodic monitoring of crop nitrogen status. The synchronization between demand and supply from all available sources including fertilizers can help to achieve higher nitrogen use efficiency. The presentinvestigation was carried out to study the threshold colour of rice leaves in terms of NDVI and SPAD values at which fertilizer N needs to be applied to achieve higher yield and fertilizer $\mathrm{N}$ use efficiency.

The study revealed that application of $30 \mathrm{~kg} \mathrm{~N} / \mathrm{ha}$ as basal dose and top dressing of $20 \mathrm{~kg} \mathrm{~N} / \mathrm{ha}$ twice at 35 and 63 DAS guided by NDVI threshold value of $0.8\left(\mathrm{~T}_{5}\right)$ was found to be superior over other treatments with respect to productivity, profitability, nutrient and energy use efficiency. It recorded highest grain yield of $4438 \mathrm{~kg} / \mathrm{ha}$ which was $30 \%$ higher than fixed schedules $\left(\mathrm{T}_{3}\right)$ and $7.1 \%$ higher than that top dressed at SPAD threshold value of $37.5\left(\mathrm{~T}_{7}\right) . \mathrm{T}_{5}$ produced maximum dry matter of $8678 \mathrm{~kg} / \mathrm{ha}$ with highest grain yield $(4438 \mathrm{~kg} / \mathrm{ha})$, straw yield $(5092 \mathrm{~kg} / \mathrm{ha})$ and harvest index $46.0 \%$.

As GreenSeeker and SPAD thresholds vary for different agro climatic conditions, study revealed that GreenSeeker threshold of 0.8 and SPAD threshold of 37.5 may be suitable for Odisha condition

\section{REFERENCES}

Artacho P, Bonomelli C and Meza F. 2009. Nitrogen Application in irrigated rice grown in mediterranean conditions: Effects on grain yield, dry matter production, nitrogen uptake, and nitrogen use efficiency. J. Plant Nutr, 32: 1574-1593.

Balasubramanian V and Hill JE. 2002. Direct seeding of rice in Asia emerging issues and strategic research needs for the 21st century, International Rice Research Institute, 13: 24-25.

Balasubramanian V, Ladha, JK, Gupta RK, Naresh R.K, Mehla R.S, Bijay-Singh and Yadvinder-Singh. 2003. Technology options for rice in the rice-wheat system in South Asia, American Society of Agronomy, 16: 115-147. 
Bijay-Singh, Sharma RK, Jat ML, Yadvinder-Singh, Varinderpal-Singh, Chandna P,Choudhary OP, Gupta R K, Jaspreet- Kaur, Thind H S and Gupta R K .2007. In-season estimation of yield potential and nitrogen management using hand- held GreenSeekerTM optical sensor in the ricewheat system in the Indo- Gangetic plain, Proc 4th Nitrogen Conference, Costa doSauiupe, Brazil, pp 223-225.

Blevins DW, Wilkison DH, Kelly BP and Silva SR. 1996. Movement of nitrate fertilizer to glacial till and runoff from a claypan soil, J. Environ. Qual, 25: 584-593.

Cai ZC, Xing GX, Yan XY, Xu H, Tsuruta H, Yagi K and Minami K. 1997. Methane and nitrous oxide emissions from rice paddy fields as affected by nitrogen fertilisers and water management, Plant Soil, 196: 7-14.

Campbell JB .2002. Introduction to remote sensing, The Guilford Press, New York 16:34-36.

Channabasavanna AS and Setty RA, 1994. Response of broadcast rice (Oryza sativa) to level of nitrogen, phosphorus and potassium and time of $\mathrm{N}$ application, Indian Journal of Agronomy, 39(3):457-459.

Chapman SC and Barreto HJ. 1995. Using a chlorophyll meter to estimate specific leaf nitrogen of tropical maize during vegetative growth, Agron. J, 89: 557-562.

Dobermann A and Fairhurst T. 2000. Rice Nutrient disorders and nutrient management, Int. Rice Res. Inst, 28: 831-890.

Fageria NK. 2010. Optimal nitrogen fertilization timing for upland rice.19th World Congress of Soil Science, Soil Solutions for a Changing World 2010, Brisbane,Australia, Published on DVD.

FAO FAOSTAT, Statistics Division. 2013. Food and Agricultural Organization of the United Nations, Rome.http://faostat. fao. org/default. Aspx.

Hasegawa T, Koroda Y, Seligma, NG and Horie T. 1994. Response of spikelet number toplant nitrogen concentration and dry weight in paddy rice, Agronomy Journal,86:673-676. 
Hirzel JA, Pedreros and Cordero K. 2011. Effect of Nitrogen Rates and Split Nitrogen Fertilization on Grain Yield and Its Components in Flooded Rice, Chilean Journal of Agricultural Research, 71(3): 437-444.

IPCC. 2007. Climate Change, impacts, adaptation and vulnerability, pp 81-82.

Ladha JK, Pathak H, Krupnik TJ, Six J and Kessel C. 2005. Efficiency of fertilizer nitrogen in cereal production: retrospect and prospects, Adv. Agron, 87: 85-156.

Liang W, Shi Y, Zhang H, Yue J and Huang G .2007. Greenhouse gas emissions from northeast China rice fields in fallow season, Pedosphere, 17: 630-638.

Li Y, Cao H, Chu Y, Deng J, Zhu R, Zhu C, Jiang X and Bai R. 2010 Effects of wheat straw returning and nitrogen application model on rice yield and soil nitrogen supply, Soils, 42:569 573.

Liu S, Zhang Y, Lin F, Zhang L and Zou J. 2014. Methane and nitrous oxide emissions from direct-seeded and seedling-transplanted rice paddies in southeast China, Plant Soil, 374: 285297.

Mahajan G, Chauhan BS and Gill MS. 2011.Optimal nitrogen fertilization timing and rate in dry-seeded rice in northwest India, Agron. J, 103: 1676-1682.

Nerson H. 1980. Effects of population density and number of ears on wheat yield and its components, Journal of Agricultural Science, 90:97-108.

Pandey RP, Dwevedi VD, Pandey A and Sharma PP .1991. Rice yield as influenced by method of sowing and weed control practices, Curr Res UnivAgricSci, 20:253-54.

Peng SB, Garcia FV, Laza RC, Sanico AL, Visperas RM and Cassman KG. 1996.Increased Nuse efficiency using a chlorophyll meter on high-yielding irrigated rice, Field Crops Res, 47: 243-252. 
Peterson TA, Blackmer TM, Francis DD, Schepers JS.1993. Using a Chlorophyll Meter to Improve N Management, Cooperative Extension. Institute of Agriculture and Natural Resources, University, Nebraska, Lincoln, USA. 13: 43-46.

Power JF and Alessi J. 1978. Tiller development and yield of standard and semi-dwarf spring wheat varieties, Agron Sustain Dev, 31:52-55.

Schepers JS. 1992. Comparison of corn leaf nitrogen concentration and chlorophyll meter reading, Communications in Soil Science and Plant Analysis, 23: 2173-2178.

Sun J, Zhang X, Jia S. 2013. The effect of soil physical and chemical properties on soil microbial community in Agro-ecosystem, Soil Crop ,02:138-144.

Tian G, Cai Z, Cao J and Li X .2001. Factors affecting ammonia volatilization from a rice-wheat rotation system, Chemosphere, 42: 123-12.

Varinderpal-Singh, Bijay-Singh, Yadvinder-Singh, Thind HS and Gupta RK, 2010. Need based nitrogen management using the chlorophyll meter and leaf colour chart in rice and wheat in South Asia, Nutr. Cycl. Agroecosyst, 88: 361-380.

Zhao J, Ni T, Xun W, Huang X, Huang Q, Ran W, Shen B, Zhang R, and Shen Q. 2017. Influence of straw incorporation with and without straw decomposer on soil bacterial community structure and function in a rice-wheat cropping system, Appl Microbiol Biotechnol, 101:1-13. 